\title{
The Use of Microbial Inoculants in Crop Production for Food Security Sustainability
}

\author{
Agbowuro, Gbenga Oluwayomi*, Ayeyo Morolake Elizabeth, Emecho Tejiri Sophia
}

Department of Biological Sciences Elizade University, Ilara Mokin, Ondo State.

* Corresponding Author email:

gbenga.agbowuro@elizadeuniversity.edu.ng

Article History

Received: 11 May 2021

Accepted: 30 July 2021

Published: 31 July 2021

Student(s)

- $\quad$ Emecho Tejiri Sophia

Academic Year: 2020-2021

Course Level: Bachelor

Course Name: B.Sc. (Microbiology)

Course year: Final Year

$\operatorname{Mentor}(s)$

- Agbowuro Gbenga Oluwayomi

- Ayeyo Moraloke Elizabeth

\section{ABSTRACT}

Increasing human population, war, climate change, herdsmenfarmers clashes, banditry, terrorism, political unrest affected crop production negatively. These factors widen the gap between food production supply and its demand. In an attempt to fill this gap, agrochemicals were used to increase crop yield to meet the food demand of the ever-increasing population. Agrochemical's introduction was accepted initially due to their quick and nonspecific actions. Decades later, these agrochemicals begin to pose threats to human and livestock health, causing land degradation, ecosystem imbalance, reduction in soil fertility and productivity. To avert the negative effects of agrochemicals on food and feed products, soil, water quality, and the environment. The use of a safe and eco-friendly alternative was developed. Microbial inoculants serve to be the best substitute for agrochemicals with substantial benefits in sustainable crop production and environmental sustainability. This review aims at updating available information on the benefits of using microbial inoculants in boosting crop production and the strategies to adopt for its effectiveness.

Keywords: Agrochemicals, crop yield, microbial inoculants

\section{Introduction}

The present human population of about 7.6 billion is expected to reach 9.8 billion or more by the year 2050 [1]. The rapid growth in the global human population gives rise to many problems such as food insecurity, hunger, and malnutrition [2]. As the world population keeps rising, the demand for food and feed products keeps rising while the productive agricultural land area available for food production continues to decrease due to industrialization, urbanization and development, destructive environmental human activities such as deforestation, unregulated mining [3] and natural disaster like flood. These problems posed a threat to global food security and malnutrition. To avert the looming problems of global food insecurity, hunger, and malnutrition, concerned bodies implemented and adopted the technology of green revolution all over the world. The green revolution rested on three principles; biochemical, mechanical, and social principles 
[4]. The principles involved the use of hybrid seeds, chemical fertilizers, pesticides, fungicides, herbicides, use of types of machinery, sophisticated irrigation facilities, and land reformation. These agricultural inputs and some other services were made available to encourage the farmers [5] in order to increase agricultural productivity.

The green revolution technology increased yield per unit area but posed some negative threat on man and the ecosystem as a result of excessive use of chemical fertilizers, herbicides and pesticides [6]. Land degradation, reduction of water quality and soil fertility, and loss of biodiversity in crops were major limitations of the Green Revolution. According to [7], most of these herbicides, pesticides, and synthetic fertilizers have carcinogenicity potential. The application of pesticides and herbicides results in the accumulation of toxic compounds in the soils [8], which also affects water quality and soil fertility. In order to fill the gap between food demand and supply to an ever-increasing population, more of the conventional agricultural inputs (chemical fertilizer, pesticides, herbicides) were being used excessively and the problems imposed by these inputs will be compounding. The problems that evolved as a result of the conventional agricultural inputs (chemical fertilizer, pesticides, herbicides, fungicides) could be resolved if the basic information and awareness concerning the utilization of soil microbes for sustainable crop production are well provided.

Soil is the major medium of growing crops. Good soil contains a large number of beneficial microbes such as fungi, bacteria, protozoa, and many more. These microbes can be found to be free-living or in a symbiotic with other organisms (s) in the soil [9]. The roles of soil microbes play in influencing soil biological management, fertility functions, and productivity cannot be overemphasized [10]. When the prevailing environmental factors are favourable, these microbes exhibit a lot of beneficial functions in the soil such as homeostasis of nutrients cycles, fixation and solubilisation of some nutrients, inhibition of the growth and development of pathogens, reduction of toxins produced by pathogen, and also help in soil amendment, supply of nitrogen, phosphorus, potassium and other nutrients and water retention especially those inhabiting the rhizosphere in their culture or natural state. All these directly or indirectly help in increasing crop yield and its sustainable productivity [11].The use of the microbiome in crop production will proffer solutions to the current issues associated with poor crop yield, food security, malnutrition, and land degradation [12-13]. Plant microbiomes are microorganisms that are found in the plant's internal tissues (endophytes) or its external surfaces (rhizosphere/rhizoplane and phyllosphere) [14]. According to [15], there are communication mechanisms and mutual recognition between the plants and microbiome-based on complex molecule exchange. These host-microbiome communications are very essential for plant health as they defend plants against biotic and abiotic stresses [16-17].

Considering the benefits of microbiomes to the crop performances and yield, environmental sustainability, and the effects of synthetic chemicals such as fertilizers, herbicides, fungicides, pesticides, etc used in agriculture to boost productivity, these microorganisms could be an alternative tool in proffering solutions to crop productivity constraints and environmental problems imposed by these synthetic inputs thereby achieving increased productivity and sustainable ecosystem. This review aims at updating the information available on the benefits of using microbial inoculants in crop production sustainability over synthetic agricultural inputs and the ways to effectively use these biological resources called microbial inoculants for sustainable crop production.

\section{Contribution of Microbial Inoculant in Crop Production Sustainability}

\subsection{Microbial inoculant as bio-fertilizer}

Improving soil fertility is one of the key strategies adopted to boost agricultural productivity. The pressure mounted by the world increasing population for food has led the farmers to continually attempt to increase the crop yield by application of expensive chemical fertilizer which increases cost of production and also has detrimental effects on the human's health and the environment. Biofertilizers are made up of active or latent cells of beneficial microbes that could either be mixed or monoculture. It is one of the most promising 
Agbowuro et al., Adv. J. Grad. Res.; Vol. 10, Issue 1, pp: 33-40, July 2021

strategy to increase crop productivity without jeopardizing the environment [18]. When applied to the plant seeds, plant parts, or the soil, it has the capability to colonize the plant rhizosphere or its tissue thereby promoting its growth and development thus increasing yield by increasing the quantity of nutrients available to the host plant. Biofertilizers contributes to the growth and development of plant through biomineralization, biofixation, biosolubilization, immobilization, production of phytohormones, siderophore, ammonia production, and inhibition of some plant pathogens growth and reduction of the toxic substance released to the host plant through the production of antibiotics, induced systemic resistance, synthesizing hydrogen cyanide (HCN) and producing lytic enzymes with the help of specific enzymes [19]. Some specific bacterial microbial inoculants that increase various plant species yield are shown in Table 1.

Table 1: Some specific bacterial microbial inoculants that increase various plant species yield [34], [37].

\begin{tabular}{lll}
\hline Crop & Microorganism & Reference \\
\hline Soybean & Bradyrhizobium japonicum & {$[26]$.} \\
& Bradyrhizobium japonicum & {$[27]$.} \\
& Azospirillum brasilense and & {$[28]$.} \\
& Bradyrhizobium japonicum & \\
Tomato & Azospirillum brasilense & {$[29]$.} \\
& Pseudomonas fluorescens & {$[30]$.} \\
& & \\
& Chryseobacteriumspp. (C138) & {$[31]$.} \\
Cowpea & Bradyrhizobium yuanmingense & {$[32]$.} \\
Maize & Pseudomonas fluorescens & {$[33]$.} \\
& Rhizobium trifolii & {$[34]$.} \\
Rice & Rhizobium leguminosarum & {$[34]$.} \\
& Bradyrhizobium sp. IRBG271 & {$[35]$.} \\
Common beans & Rhizobium tropici & {$[36]$.} \\
& Rhizobium leguminosarum sv. & \\
\hline
\end{tabular}

The use of biofertilizer is environmentally friendly and centre on a renewable energy source which makes it cost-effective with high investment return in crop production compared to chemical fertilizer that its production is an energy-intensive process which is costlier and unaffordable to farmers thereby resulting in the high cost of production [20]. It has been reported that the application of biofertilizers increases some secondary metabolites like phenol, carotenoids content, flavonoid, etc. in the host plant [19]. [21] reported a 58.72 and $51.43 \%$ increase in total phenolic content in spinach inoculated than in the uninoculated control. These secondary metabolites have been proved to be beneficial to people living with or at risk of cancer, cardiovascular disorders, and some other diseases [22]. The biofertilizers not only make nutrients available to plants for better yield but also increase crop quality.

\subsection{Microbial Inoculant as bio-control agents}

The use of microbial inoculant as a biocontrol agent is gaining more popularity over its chemical which its abusive use have contributed to poor soil fertility and productivity, land and environmental degradation that have constituted adverse effects on human health and the ecosystem at large. Many microorganisms exhibit some herbicidal, antifungal, and antibacterial properties which qualify them as biocontrol agent suitable as biopesticides, bioherbicides, and biofungicides when properly prepared and applied.

Biopesticides are those microbes that are capable of promoting the growth and development of host plant by inhibiting the growth and multiplication of phytopathogenic agents using different mechanisms such as the production of antibiotics, extracellular hydrolytic enzymes, siderophores, and induction of systemic 
resistance [23]- [24]. The roles biopesticides are playing in reducing the quantity of harmful residual contents left in food, fodder, and feeds caused by the use of chemical pesticides and in controlling environmental pollution cannot be quantified [25].

Herbicides are phytotoxic chemical pesticides designed to inhibit the germination of plant or weed seeds or to control or destroy weeds and plants with varied specifications. Apart from the high cost of chemical herbicides, it posed a lot of negative effects on the ecosystem and threatened human and livestock health due to its residual contents on the plant parts [38]. Moreover, the abuse of chemical herbicides by some farmers rapidly reduces soil fertility and productivity.

The use of microorganisms that exhibit herbicidal properties in inhibiting the weed seeds germination and destroying weeds offer a sustainable, cost-effective, and ecosystem-friendly approach to controlling weeds for better agricultural productivity. When live or latent microorganisms that exhibit herbicidal properties are formulated either in mixed or monoculture to control weeds is called bioherbicides. When these bioherbicides are applied to the soil, roots, seeds, or seedlings, the growth of the emerging roots and the shoots are suppressed. Table 2 shows some microbes used as biocontrol agents.

Table 2: Some used as Microbial Inoculants as Biocontrol Agents

\begin{tabular}{|c|c|c|c|}
\hline $\mathrm{S} / \mathrm{N}$ & Microbes & Pathogens & References \\
\hline \multirow[t]{6}{*}{1.} & Aspergillus fumigatus & Phytophthora infestans & [23] \\
\hline & Aspergillus niger & & \\
\hline & Penicillium funiculosum & & \\
\hline & Penicillium aurantiogriseum & & \\
\hline & Penicillium citrinum & & \\
\hline & Trichoderma koningii & & \\
\hline \multirow[t]{4}{*}{2.} & Bacillus amyloliquefaciens, & fungi pathogens & [39] \\
\hline & Amphibacillus xylanus, & & [40] \\
\hline & Microbacterium & & \\
\hline & Sporolactobacillus inulinus & & \\
\hline \multirow[t]{2}{*}{3.} & Bacillus subtilis & Aspergillus flavus and aflatoxin & [41] \\
\hline & & production & [40] \\
\hline 4. & Mitsuaria sp. & bacterial leaf spot & [42] \\
\hline 5. & Pseudomonads & Fusarium wilts & [42] \\
\hline 6. & Bacillus spp & microbial diseases & [42] \\
\hline 8. & Colletotrichum coccodes & Fusarium spp. & [43] \\
\hline 9. & Trichoderma harzianum & wood rots & [44] \\
\hline
\end{tabular}

\subsection{The use of microbial inoculants in the food processing industry}

Microbial inoculants are used for food fermentation [45], an improvement on the food, feed, and fodder properties such as texture, shelf-life, aroma, etc., and its nutritional properties like vitamins and minerals [46]. Lactic acid bacteria is a microorganism that is used in the maintenance of food and feed products by inhibiting food spoilage as it has been documented to be safe for consumption [47]. It also serves as probiotics for the digestive systems [25]. The use of these microbial inoculants lowers the cost of production and does not have residual effects on the human and livestock's body system.

\section{Challenges and way forward in using microbial inoculant}

The use of microbial inoculants in crop production is promising and highly profitable. Adoption of microbial inoculants on large scale will not be easily feasible especially in developing nations where the farmers are not fully aware or have complete information about the proper usage of it. However, storage and distribution seem to be difficult before getting to the end-user farmers. The use of microbial inoculants in crop production and farm produce processing and storage may not give a maximum response as expected if the prevailing environmental conditions such as soil conditions, climatic variables, moisture regime are 
not favourable. Proper timing and strict procedures of application are very essential as excessive heat or desiccation may reduce the inoculant efficiency.

The producer recommended storage conditions should be strictly followed [48]. Poor agronomic practices, the presence of pollutants, and numerous exudates from the plant roots may hinder the effectiveness of microbial inoculant on the soil. The end-users of these microbial inoculants should be aware of the ways these inoculants act, storage conditions, time, mode, and methods of application for an effective response of the microbial inoculants. The user instructions should always come with the products to them to be more acceptable.

Competition between inoculated microbes and soil natural flora in the soil could reduce inoculant efficiency. Some of the inoculants are host specific, application of microbial inoculant to a specific host plant is highly essential, imperfect host-plant specificity can reduce inoculant efficiency or total failure. Perfect inoculant-host plant-specific should be well spelled out by the producers. Farmers should be educated on the implications of using imperfect inoculants on the host plant.

The compatibility of microbial inoculant with agrochemicals is a great limitation as the survival of the inoculant may be reduced [49]. It becomes imperative to find out the agrochemicals that are compatible with the cell protectors in the inoculants through studies and trials to avoid inoculant failure due to agrochemical application [28]. There is a need to investigate the agrochemical active ingredients that can inhibit the performance of microbial inoculants for them to be more acceptable.

The benefits of using microorganisms to boost crop yield with reduced cost are leading some farmers with little knowledge in microbial inoculants production to produce their inoculant. With this practice, the threat of abuse of microbial inoculant is looming in agriculture as its benefits may be jeopardized and also cause problems to the plant and soil. The availability of the efficient microorganism strains to develop into inoculants [50] and the development of genetic variability among strains over time is a challenge [37]. Unqualified scientists and farmers should not be allowed to produce microbial inoculants [51]. The selection of wrong microbial strains for inoculant production is risky, because the selected microbial strain selected may be pathogenic to plants and non-target organisms [52].

\section{Conclusions}

Considering the great benefits of using microbial inoculant in crop productivity and produce processing, ranging from high crop yield to environmental sustainability. It serves as an alternative to putting an end to the negative effects of agrochemicals. The elimination of hitches in commercializing microbial inoculants should be speedily working towards. If all these constraints are taken care of through proper studies and field trials, the use of agrochemicals will lose its popularity. Hence our environment will be safe. Good and healthy food, feed, and fodder that is free of chemical residual contents that have various health implications on man and livestock will be available. Identification, molecular characterization, and screening of indigenous microbes for the production of inoculants should be a continuous effort. Improvement on these microbial inoculants should be done using genetically modifying technologies. The efficiency of different microbial inoculants across different agro-climatic conditions, soil types and conditions, farming routine operations, and efficient mode of application to improve survival of the inoculant should be studied both in the greenhouse and in the field to have precise recommendations. Proper studies and trials are needed on how microbial inoculants interact with other agrochemicals and the understanding of inoculation mechanisms should be continuous. There should be a policy and regulatory body to ensure that the inoculants that will be prepared and released to the market by a licensed and registered scientific laboratory or company under specialized conditions are of international standard. International bodies, government tiers, non-governmental organizations, and other concerned individuals should put resources together to fill the knowledge gaps and improve research in the area of microbial inoculants in order achieve success in sustainable crop production and food security. Suitable mechanisms of preserving, transportation, and marketing of the inoculant should be properly working on. Moreover, an accessible global database for all the plant microbiomes should be created. The researchers and agricultural extension agents should 
collaborate to ensure that the end-user farmers are properly educated on the proper use and handling of the inoculants. The misconceptions that all microorganisms are disease causative agents should be erased from the end-user's mindset.

\section{Declarations}

\subsection{Acknowledgments}

We acknowledge Dr. Abdul Momoh of Microbiology unit of the Department of Biological Science, Elizade University for providing some academic materials when writing this review.

\subsection{Competing Interests}

The authors declared that no conflict of interest exists.

\section{How to Cite this Article:}

G. O. Agbowuro, M. E. Ayeyo, and T. S. Emecho, "The Use of Microbial Inoculants in Crop Production for Food Security Sustainability”, Adv. J. Grad. Res., vol. 10, no. 1, pp. 33-40, Jul. 2021. https://doi.org/10.21467/ajgr.10.1.33-40

\section{References}

[1] United Nations. World population prospects: the 2017 revision. Geneva: United Nations Department of Economic and Social Affairs, 2017.

[2] FAO. The State of Food Insecurity in the World Economic crises - impacts and lessons learned Food and Agriculture Organization of the United Nations, Rome., 2009.

[3] M.M. Saad, A.A. Eida and H. Hirt, "Tailoring plant-associated microbial inoculants in agriculture: a roadmap for successful application” Journal of Experimental Botany, vol. 71, no. 13, pp. 3878-3901, 2020. doi:10.1093/jxb/eraa111

[4] P.B. Hazell, "The Asian Green Revolution" International Food Policy Research Institute, 911. 2009.

[5] J.N. Pretty, "Agri-culture: Reconnecting People" Land and Nature. Earthscan, London. 2002.

[6] D. Tilman, "The greening of the green revolution." Nature, vol. 396, pp. 211-212.1998.

[7] C.A. Damalas and I.G Eleftherohorinos "Pesticide exposure, safety issues, and risk assessment indicators." International Journal of Environmental Resource and Public Health, vol.8, no. 5, pp. 1402-1419, 2011. doi: 10.3390/ijerph8051402

[8] A. Baez-Rogelio, Y.E. Morales-Garcia, V. Quintero-Hernandez and J. Munoz-Rojas, "Next generation of microbial inoculants for agriculture and bioremediation," Microbial Biotechnology, vol. 10, no. 1, pp. 19-21, 2017. doi:10.1111/1751-7915.12448

[9] K.P Smith and R.M Goodman, "Host variation for interactions with beneficial plant associated microbes," Annual Review of Phytopathology, vol. 37 pp. 473-491, 1999.

[10] B.K. Singh and P. Trivedi, "Microbiome and future for food and nutrient security," Microbial. Biotechnology. Vol. 10, no. 1, pp. 5053, 2017. doi: 10.1111/1751-7915.12592

[11] S.R. Sammauria, K.K Pushpa, J. Singh and J. T. Kumar, "Microbial inoculants: potential tool for sustainability of agricultural production system," Archives of Microbiology, vol. 202, pp. 677-693, 2020. https://doi.org/10.1007/s00203-019-01795-w

[12] National Academies of Sciences, Engineers and Medicine, "Science Breakthroughs to Advance Food and Agricultural Research by 2030," National Academies Press. 2030

[13] Z. Qiua, E. Egidia, H. Liua, S. Kaura and B.K. Singh, "New frontiers in agriculture productivity: Optimised microbial inoculants and in situ microbiome engineering," Biotechnology Advances, vol. 37, pp. 107371, 2019. doi.org/10.1016/j.biotechadv.2019.03.010

[14] M.T. Agler, J. Ruhe, S. Kroll, C. Morhenn, S. T. Kim, D. Weige and E.M. Kemen, "Microbial hub taxa link host and abiotic factors ti plant microbiome variation," PLoS Biology, vol. 14, no. 1, e100235, 2016. https://doi.org/10.1371/journal.pbio.1002352

[15] B.J. Lugtenberg, T. F Chin-A-Woeng, and G. V.Bloemberg, "Microbe-plant interactions: principles and mechanisms", Antonie Van Leeuwenhoek, vol. 81, pp. 373-383. 2002.

[16] N. Weyens, D. van der Lelie, S. Taghavi, L. Newman and J. Vangronsveld, "Exploiting plant-microbe partnerships to improve biomass production and remediation," Trends in Biotechnology, vol. 27, pp. 591-598, 2009. https://doi.org/10.1016/j.tibtech.2009.07.006

[17] C. Dimkpa, T. Weinand and F. Asch, "Plant-rhizobacteria interactions alleviate abiotic stress conditions," Plant Cell Environment, vol. 32, pp. 1682-1694. 2009. doi: 10.1111/j.1365-3040.2009.02028.x.

[18] D. Kour, K.L. Rana, A.J. Yadav, N. Yadav, M. Kumar, V. Kumar, P. Vyas, H.S. Dhaliwal, A.K Saxena, "Microbial biofertilizers: Bioresources and eco-friendly technologies for agricultural and environmental sustainability," Biocatalysis and Agricultural Biotechnology Vol. 23, 101487, 2020. https://doi.org/10.1016/j.bcab.2019.101487

[19] E. T. Alori, and O. O. Babalola, "Microbial Inoculants for Improving Crop Quality and Human Health in Africa," Frontier in Microbiology, vol. 9, 2213. 2018. doi: 10.3389/fmicb.2018.02213

[20] G. O. Agbowuro and A. E. Salami, "Performance of Low-N Maize Hybrids (Zea mays L.) and Relationship among Traits under varied Soil Nitrogen Conditions," Journal of Researches in Agricultural Sciences, vol. 3, no. 1\&2, pp. 52-56, 2015.

[21] M. Khalid, D. Hassani, M. Bilal, F. Asad, and D. Huang, "Influence of bio-fertilizer containing beneficial fungi and rhizospheric bacteria on health promoting compounds and antioxidant activity of Spinacia oleracea L.," Botany Studies, vol. 58:35, 2017. doi: $10.1186 / \mathrm{s} 40529-017-0189-3$ 
Agbowuro et al., Adv. J. Grad. Res.; Vol. 10, Issue 1, pp: 33-40, July 2021

[22] J. Rodríguez-Morató, L. Xicota, M. Fitó, M. Farré, M. Dierssen and R. de la Torre, "Potential role of olive oil phenolic compounds in the prevention of neurodegenerative diseases," Molecules, vol. 20, pp. 4655-4680, 2015. doi: 10.3390/molecules20034655

[23] A. Rani, M. N. Bhat, and B. P. Singh, "Effect of potato phylloplane fungi on potato late blight pathogen Phytophthora infestans," Journal of Mycology and Plant Pathology, vol. 37, pp. 413-417.

[24] D. Chandler, G. Davidson, W. P. Grant, J. Greaves and G. M. Tatchell, "Microbial biopesticides for integrated crop management: an assessment of environmental and regulatory sustainability". Trends in Food Science and Technology, vol. 19 no. 5, pp. 275-283, 2008. DOI: $10.1016 /$ j.tifs.2007.12.009

[25] P. Bhargava, A.K Singh and R. Goel, "Microbes: Bioresource in Agriculture and Environmental Sustainability," D.P. Singh et al. (eds.), Plant-Microbe Interactions in Agro-Ecological Perspectives. Springer Nature Singapore Pte Ltd. 2017361 DOI: 10.1007/978981-10-5813-4_18

[26] M. Leggett, M. Diaz-Zorita, M. Koivunen, R. Bowman, R. Pesek, C. Stevenson, T. Leister, "Soybean response to inoculation with Bradyrhizobium japonicum in the United States and Argentina," Agronomy Journal, vol. 109, pp.1031-1038, 2017. https://doi.org/10.2134/agronj2016.04.0214

[27] J. Ulzen, R.C. Abaidoo, N.E. Mensah, C. Masso, A.H AbdelGadi, "Bradyrhizobium inoculants enhance grain yields of soybean and cowpea in northern Ghana," Frontier in Plant Science, vol. 7 pp. 1-9, 2016. https://doi.org/10.3389/fpls.2016.01770

[28] M. Hungria, F.M. Loureiro, I.C. Mendes, R. J. Campo and P. H. Graham, "Inoculant preparation, production and application” In: Werner D, Newton WE (eds) Nitrogen fixation agriculture, forestry, ecology and the environment. Springer, Dordrecht, pp 224-253, 2005.

[29] E.T. Alfonso, A. Leyva and A. Hernández, "Microorganismos benéficos como eficientes para el cultivo del tomate (Lycopersicon esculentum, Mill)," Revista Colombiana de Biotecnología, vol. 7, no. 2 pp. 47-54, 2005.

[30] N.K Ahirwar, G. Gupta, V. Singh, R.K. Rawlley and S. Ramana, "Influence on growth and fruit yield of tomato (Lycopersicon esculentum Mill.) plants by inoculation with Pseudomonas fluorescence (SS5): possible role of plant growth promotion," Int. J. Curr. Microbiol. Appl. Sci., vol. 4, pp. 720-730, 2015. https://doi.org/10.1016/j.sjbs.2012.10.004

[31] W. Radzki, M.F.J, Gutierrez, E. Algar, G.J.A Lucas, A. GarcíaVillaraco and B. Ramos Solano, "Bacterial siderophores efficiently provide iron to iron starved tomato plants in hydroponics culture," Antonie Van Leeuwenhoek, vol. 104, pp. 321-330, 2013. doi: 10.1007/s10482-013-9954-9

[32] E.G. Padilla, B. Ruiz-Díez, M Fernández-Pascual, R. López Sánchez, E. Bloem, B. Eichler-Löbermann, "Inoculation with native bradyrhizobia strains improved growth of cowpea plants cultivated on a saline soil," Communication in Soil Science and Plant Analysis, vol. 47, pp. 2218-2224, 2016. https://doi.org/10.1080/00103624.2016.1228950

[33] I. E. Sandini, F. Pacentchuk, M. Hungria, M. A. Nogueira, S.P. Cruz, A.S Nakatani, and R.S. Araujo, "Seed inoculation with Pseudomonas fluorescens promotes growth, yield and reduces nitrogen application in maize," International Journal of Agriculture and Biology, vol. 22, pp. 1369-1375, 2019. https://doi.org/10.17957/IJAB/15.1210

[34] M.A.B Mia and Z. H. Shamsuddin, "Rhizobium as a crop enhancer and biofertilizer for increased cereal production," African Journal of Biotechnology, vol. 9, no. 37, pp. 6001-6009, 2010.

[35] F.M Mercante, A.A. Otsubo and O. R. Brito, "New native rhizobia strains for inoculation of common bean in the Brazilian savanna," Rev Bras Ciênc Solo vol. 41:e0150120, 2017. https://doi.org/10.1590/18069657rbcs20150120

[36] T.Y Samago, E.W. Anniye and F.D Dakora, "Grain yield of common bean (Phaseolus vulgaris L.) varieties is markedly increased by rhizobial inoculation and phosphorus application in Ethiopia," Simbiosis, vol. 75, pp. 245-255, 2019. https://doi.org/10.1007/s13199017-0529-9

[37] M.S. Santos, M.A. Nogueira and M. Hungria, "Microbial inoculants: reviewing the past, discussing the present and previewing an outstanding future for the use of beneficial bacteria in agriculture," AMB Express, vol, 9:205, 2019. https://doi.org/10.1186/s13568019-0932-0

[38] W. Aktar, D. Sengupta and A. Chowdhury, "Impact of pesticides use in agriculture: their benefits and hazards," Interdisciplinary Toxicology, vol. 2, no. 1, pp. 1-12. doi: 10.2478/v10102-009-0001-7

[39] L. Cavaglieri, L. Andrés, M. Ibañez and M. Etcheverry, "Rhizobacteria and their potential to control Fusarium verticillioides, effect of maize bacterisation and inoculum density," Antoinie Van Leeuwenhoek, vol. 87 pp. 179-187, 2005. doi: 10.1007/ s10482-0043193-z

[40] A. Nesci, R. Bluma and M. Etcheverry, "In vitro selection of maize rhizobacteria to study potential biological control of Aspergillus section flavi and aflatoxin production," European Journal of Plant Pathology, vol. 113, pp. 1-13, 2005. doi: 10.1007/s10658-005$5548-3$

[41] N. Kimura and S. Hirano, "Inhibitory strains of Bacillus subtilis for growth and aflatoxin-production of aflatoxigenic fungi," Agriultural and Biological Chemistry, vol. 52, pp. 1173-1179, 1988. doi:10.1080/00021369.1988.10868840

[42] M.V. Cepeda, "Effects of Microbial Inoculants on Biocontrol and Plant Growth Promotion Plant Pathology,".Master of Science, Ohio State University, Columbus, OH. 102. 2012. doi: 10:P10_ACCESSION_NUM:osu1345239027

[43] O.O. Babalola, "Pectinase and cellulase enhance the control of Abutilon theophrasti by Colletotrichum coccodes," Biocontrol Science and Technology, vol. 17, pp. 53-61, 2007. doi: 10.1080/09583150600828783

[44] G.E. Harman, M. Lorito and J.M. Lynch, "Uses of Trichoderma spp. to alleviate or remediate soil and water pollution," in Advances in Applied Microbiology, eds A. I. Laskin, J. W. Bennett, and G. M. Gadd (San Diego, CA: Elsevier Academic Press), pp. 313-330, 2004. doi: 10.1016/S0065-2164(04)56010-0

[45] A.R. Borneman, S.A. Schmidt and I.S. Pretorius, "At the cutting-edge of grape and wine biotechnology," Trends in Genetics, vol. 29, no. 4, pp. 263-271, 2013. doi: 10.1016/j.tig.2012.10.014

[46] L.C. Vitorino and L.A Bessa, "Technological microbiology: development and applications," Frontier in Microbiology, vol. 8:8272, 2017. doi: $10.3389 /$ fmicb. 2017.00827

[47] D.M. Ikeda, E. Jr. Weinert, K.C. Chang, J.M. McGinn, S. A. Miller, Keliih C. oomalu and M.W DuPonte, "Natural farming: lactic acid bacteria," Sustainable Agriculture, vol. 8, pp. 3-4, 2013. 
[48] H.J Patil and M.K. Solanki, "Microbial Inoculant: Modern Era of Fertilizers and Pesticides D.P. Singh et al. (eds.)," Microbial Inoculants in Sustainable Agricultural Productivity, Springer India, 2016:31. DOI 10.1007/978-81-322-2647-5_19

[49] R.J. Campo, R.S. Araujo and M. Hungria, "Nitrogen fixation with the soybean crop in Brazil: compatibility between seed treatment with fungicides and bradyrhizobial inoculants," Symbiosis, vol. 48, pp. 154-163, 2009. https://doi.org/10.1007/BF03179994

[50] M.O. Callaghan, "Microbial inoculation of seed for improved crop performance: issues and opportunities." Applied Microbiology and Biotechnology, vol. 100, pp. 5729-5746, 2016. doi: 10.1007/s00253-016-7590-9

[51] M. Hungria, M. A. Nogueira and R.S. Araujo, "Co-inoculation of soybeans and common beans with rhizobia and azospirilla: strategies to improve sustainability," Biology and Fertility of Soils, vol. 49, pp. 791-801, 2013. https://doi.org/10.1007/s00374-012-0771-5

[52] V. Cuddeford and J.T. Kabaluk, "Alternative regulatory models for microbial pesticides," in The Use and Regulation of Microbial Pesticides in Representative Jurisdictions Worldwide, eds J. T. Kabaluk, A. M. Svircev, M. S. Goettel, and S. G. Woo (St. Paul, MN: IOBC Global), 94-98, 2010.

\section{Publish your books with AIJR publisher-}

- $\quad$ Publish with ISBN and DOI.

- Publish Thesis/Dissertation as Monograph.

- Publish Book Monograph.

- Publish Edited Volume/ Book.

- Publish Conference Proceedings

- Retain full copyright of your books.

Submit your manuscript at books.aijr.org
Publish your research article in AIJR journals-

- Online Submission and Tracking

- Peer-Reviewed

- Rapid decision

- Immediate Publication after acceptance

- Articles freely available online

- Retain full copyright of your article.

Submit your article at journals.aijr.org 